Greenwich papers

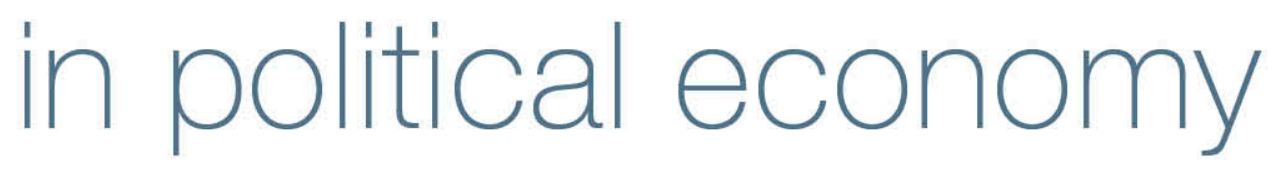

\title{
Subordinate Financialization in Emerging Capitalist Economies
}

\author{
Bruno Bonizzi, University of Hertfordshire; \\ Annina Kaltenbrunner, Leeds University Business School; and \\ Jeff Powell, University of Greenwich
}

\section{Abstract}

In the explosion of literature on financialization, there is a much smaller but growing interest in what the phenomenon means for emerging capitalist economies (ECEs). We hold that for agents located in ECEs, the encounter with financialization is from a subordinate position: first, in relation to global production, ECE firms occupy subordinate locations in global production networks, providing cheap labor and raw, or at best, intermediate inputs; Second, in relation to global finance, ECEs are structurally subordinated to ACEs, that is, both trade and the most liquid capital markets are denominated in the currency of ACEs. Subordination in production means firms based in ECEs are able to capture less of the value created than firms higher in the hierarchy and must pay more to hedge macroeconomic risk. In circulation, strategies may emerge in ACEs wherein increased household indebtedness and/or asset market inflation maintain aggregate demand. In finance, ECEs' subordinate position in relation to money and capital markets means that capital inflows are predominantly short-term, seeking financial yields rather than assuming productive risk. The results are continued volatility, external vulnerability and subordination to the currencies of the ACEs, which themselves serve to further deepen domestic financialization. We conclude that, while by no means pre-destined, financialization as experienced in ECEs may serve to further cement their subordinate position in the global structure.

\author{
Year: 2019 \\ No: GPERC69
}


Keywords: Financialization, financialized capitalism, global production networks, world money, dependency

JEL codes: F65, F54, F36, B50

\section{Corresponding authors:}

Bruno Bonizzi, University of Hertfordshire, b.bonizzi@herts.ac.uk Annina Kaltenbrunner, Leeds University Business School,

A.Kaltenbrunner@leeds.ac.uk

Jeff Powell, University of Greenwich, j.powell@gre.ac.uk

A future version of this working paper is to appear as a chapter in the upcoming Routledge International Handbook of Financialization, edited by Natascha van der Zwan, Daniel Mertens and Philip Mader. 


\section{Introduction}

In the explosion of literature on financialization, there is a much smaller but growing interest in what the phenomenon means for emerging capitalist economies (ECEs) (Bonizzi, 2013). Much of the literature that focuses on the advanced capitalist economies (ACEs) lacks a clear theory of financialization. This absence becomes even more problematic when the lens is used to attempt to describe and understand changes in ECEs.

The theory of financialization adopted here draws a necessary distinction between processes which are cyclical in nature, and secular changes in the relations of capitalist accumulation (Powell, 2018). The former are both temporally and spatially limited, with financialization giving way to de-financialization. The latter mark the emergence of a new stage of mature capitalism financialized capitalism - wherein the passage of capital through its various forms - in Marxist terms, from money capital to productive capital to commodity capital, and back again - is occurring at the global level, rather than within the nation-state. The last two decades have witnessed the realization of this process, first theorized in the 1970s with the rise of the multinational corporation (Palloix, 1975). Whereas this internationalization had previously been limited to financing and commodity circulation, it now includes the genuine internationalization of production itself. Within this transformation, finance plays a catalytic role in the extension, expansion and intensification of capitalist accumulation; at the same time, it is afforded unprecedented opportunities for exploitation and expropriation, both legal and otherwise.

Theorizing financialized capitalism as a global phenomenon in this way, requires us to confront how it emerges from and plays out across a hierarchical and uneven global landscape. We hold that for agents located in ECEs, the encounter with both cyclical processes and secular stage, is from a subordinate position. This subordination is approached from two analytical vantage points. First, in relation to global production, ECE firms generally occupy subordinate locations in global production networks, providing cheap labor and raw, or at best, intermediate inputs. This structural subordination in global production, among other things, mediates ECEs' relations to financial markets, both as potential contenders for lead firm position, and power and position within the network itself.

Second, in relation to global finance, ECEs are structurally subordinated to ACEs, that is, both trade and the most liquid capital markets are denominated in the currency of ACEs. The hegemonic position of the capital markets of the ACEs, especially the United States, is bound up with the dominant role of their currencies (Kaltenbrunner and Lysandrou, 2017). ECE currencies, on the other hand, sit on the lower end of the hierarchy, a fact that fundamentally shapes their interaction with financial markets (Powell, 2013; Prates and Andrade, 2013; Kaltenbrunner, 2015; Bonizzi, 2017a).

In what follows, we attempt to advance our understanding of how subordinate financialization emerges from and plays out in the realms of production, circulation and finance in ECEs. In production, lead firms within cyclical limits may be able to capture profits across global production networks which can be used to pay dividends, buyback shares, boost management salaries or purchase financial assets, with possibly deleterious effects for fixed investment. Even where such financial artistry meets its limits, globalized firms must continue with their engagement with financial products which help them manage increasingly complex networks of uncertainty. Their subordination in international production means firms based in ECEs are able to capture less of the value created than firms higher in the hierarchy and must pay more to hedge macroeconomic risk. Their subordinate location in relation to markets and currencies means their 
rising engagement with financial markets, either as a result of their lead firm position or in an attempt to strengthen their position in the network, take on potentially different forms than those observed in ACEs (e.g. the relative importance of foreign currency debt). These forms bring with it increased volatility, external vulnerability and financial instability.

In circulation, strategies may emerge in ACEs wherein increased household indebtedness and/or asset market inflation maintain aggregate demand. Lower levels of income and wealth in ECEs may circumscribe such a model, encouraging the turn to export-led growth, a pattern consistent with their subordinate position within global production networks. This, in turn, encourages the development of domestic financial markets and may put downward pressure on wages, benefits and taxes which underpin systems of social reproduction (e.g. health, education and unemployment insurance), encouraging a turn towards private welfare provision.

Finally, ECEs' subordinate position in relation to money and capital markets means that capital inflows are predominantly short-term, seeking financial yields rather than assuming productive risk. The results are continued volatility, external vulnerability and subordination to the currencies of the ACEs, which themselves serve to further deepen domestic financialization. By highlighting the potentially negative implications, we conclude that, while by no means predestined, financialization as experienced in ECEs may serve to further cement their subordinate position in the global structure.

\section{Internationalization of Production}

The first transformation of global capital accumulation considered crucial to conceptualize financialization phenomena in ECEs is the internationalization of production, that is the creation of global networks of production, transforming value creation and labor relations. As the literature on Global Value Chains (GVCs) and Global Production Networks (GPNs) shows, large firms, more often than not originating from the capitalist core, have disaggregated production processes and distributed them over the globe ranging from loose relationships such as competitive customersupplier relations to tight intra-firm relations (Gereffi et al., 2005). Although specifics depend on the actual configuration of the network, common to these geographically disaggregated production processes is the existence of uneven power relations and extraction of value from weaker parts of the chain which frequently concentrate on lower wage production (Bair, 2005). These are often located in the Global South but also in ACE countries such as Spain, Italy or Portugal. While the actual generation of value is increasingly dispersed geographically, profits continue to be captured in the capitalist core.

So far, the discussion of how this international reorganization of production shapes, and is in itself shaped by financialization has been rather limited (Powell,2018). In their seminal work, Milberg and Winkler $(2008,2010)$ argue that US firms have generated higher profits due to the mark-ups generated from their powerful positions in GVCs/GPNs, towards both suppliers and workers, which has allowed them to sustain financialization processes through freeing up resources for financial investments. Baud and Durand (2012) add to this by highlighting the ability of lead firms to free cash and reduce financing costs by transferring the need to hold inventories onto their suppliers and extend supplier payment periods. Rather than reinvesting these profits in core activities, they were used to pay higher dividends, buy back shares to drive up stock prices, and pursue mergers and acquisitions. This argument is confirmed econometrically by Durand and Gueuder (2016) and Auvray and Rabinovich (2017) who show that US firms' offshoring decisions were related to the slowdown in gross fixed capital formation. 
These changes in international production also have significant effects on ECE firms. On the one hand, although still limited, a few ECE firms (e.g. Tata from India or Embraer from Brazil) have turned themselves into global players and lead firms of global and regional production networks (Mathews, 2006; Unctad, 2007). In line with the argument above, the resulting pooling of profits in the head offices of these firms has generated resources (Toporowski 2009) which could be diverted into financial markets. More generally, their internationalization requires, and indeed enables, Non-Financial Corporations (NFCs) to operate in different financial markets and currencies to obtain funding, hedge currency and operational risks, and invest in financial assets. These new risks and opportunities require increased financial sophistication and tie NFCs' operations to (international) financial markets.

On the other hand, financialization can become a crucial factor in determining a firm's 'competitiveness' both between lead firms and within the network itself (Graser, 2010; Hiratuka and da Rocha, 2015). For example, if global leadership is achieved through mergers and acquisitions both the cost of external financing and large cash holdings are important to take advantage of opportunities and/or fend off hostile takeovers. This is more likely in the case of ECE firms which do not start from a dominant position. Moreover, Randøy et al. (2001: 667) argue that "the global wave of mergers and acquisitions makes it important for companies to boost stock price in order to maintain influence after a potential merger and protect themselves from being taken over".

At the same time, internationalization becomes part and parcel of a more financially-oriented firm strategy. Hiratuka and Sarti (2011) and Carmody (2002) show for Brazil and South Africa respectively that in several cases the internationalization of domestic firms were aimed explicitly at becoming global players to boost their shareholder value and ability to leverage. This echoes results by Palpacuer et al. (2006) who show for large French agribusinesses that once exposed to international financial markets, further internationalization became an important element of "financial success". According to their results, large international (institutional) investors want global players which can diversify their assets and income streams and are powerful actors in the market. Similarly, Montalban and Sakinç (2013) argue that externalization and outsourcing are important consequences of shareholder value orientation, as these practices can decrease the level of capital used and increase returns on assets.

Whereas these processes are likely to be found in ACEs, we contend that in the case of ECEs they will be mediated through their subordinate position in financial and product markets (Painceira, 2011; Powell, 2013; Kaltenbrunner and Painceira 2016). As to financial markets, whereas ACEs' firms can largely fund themselves in domestic financial markets and currencies, recent surges of ECEs' NFCs borrowing have been predominantly in foreign currency and on international financial markets (Bruno and Shin 2015, McCauley, McGuire et al. 2015). This not only deepens their vulnerability to exchange rate changes but also ties them further to financial markets when attempting to hedge the resulting risk. As a result, several ECEs, such as Brazil, Mexico and Poland, have seen a substantial increase in domestic derivatives markets (Farhi and Borghi, 2009). In several cases, such as the cellulose producer Aracruz in Brazil or the tortilla maker Gruma in Mexico, these operations also turned speculative and led to substantial losses in the international financial crisis of 2008.

At the same time, the predominance of debt issues on international financial markets (offshore), combined with a generally larger share of foreign investors in domestic debt markets, has deepened their vulnerability to international market conditions and required a more sophisticated management of the resulting risks. One distinct element of ECE firm financialization 
has been the substantial increase in cash holdings (Karwowski, 2012; Powell,2013;) which were, at least partly, precautionary (Demir 2009, Akkemik and Özen 2014). One could argue that international investors are more forceful in putting shareholder value pressures on domestic NFCs. These global operators with vast international portfolios can easily adjust their positions. This gives these institutions a higher possibility of "exit" hence putting pressure on domestic NFCs. Offshore issuance also means that the debt is issued under the law of the country of arbitration which reduces the influence of national legal systems and more generally the reach of the ECE state. Arguably, the terms of these debt contracts will be designed by the large international financial institutions intermediating and marketing the debt, which potentially endows them with an informational and operational advantage (e.g. with regards to their underlying risks).

Finally, there is some evidence that ECE firms' internationalization and increased financialization has interacted with the financialization of other sectors, although experiences vary from country to country and more research is needed. For example, the increased financial needs of ECEs have required increased financial sophistication from domestic banking systems and/or fostered foreign bank entry to fill the void. Reflecting another element of ECEs' financial subordination, foreign banks tend to have better access to international financial markets and experience and information on offshore markets which gives them an advantage over domestic banks (Pelletier 2018).

\section{Internationalization of Circulation and Profit Realization}

As production becomes internationalized, new issues emerge in the phase of profit realization. In the present conditions of increasing concentration and intensive exploitation of global productive networks, companies are capable of holding down labor costs; low wages in turn create the issue of ensuring adequate effective demand to allow profit realization and the continuation of capital accumulation. Financialization has in this sense been understood as a way to ease the problem of low demand and thus counter the potential stagnation tendencies of global capitalism (Harvey 2011; Magdoff and Sweezy 1987). This line of thought also finds echoes in the Post Keynesian and 'regulationist' literature that focuses on a "finance-dominated" accumulation regime where financial dynamics affect aggregate demand (Boyer 2000; Hein 2012).

In this line of thought, financialization can stimulate aggregate demand through two main channels: asset price inflation and increasing indebtedness. Rising asset prices - especially housing - and increasing credit to households have been crucial to stimulate demand and sustain accumulation, through a combination of reduced saving and wealth effects on consumption (Crouch 2009; Cynamon and Fazzari 2008). At the global level, the location of production and realization of profits through these mechanisms do not have to coincide: surplus value extracted in one country may well be exported and realized as profit in another, where asset price inflation and indebtedness fuel demand. In an internationalized and financialized world economy, the mechanism that sustains aggregate demand and profit realization in individual countries can therefore be either (net) exports or debt-fueled consumption.

Financialization in ECEs needs to be understood in relation to these global patterns of circulation and profit realization. Many ECEs have relied on an export-oriented growth strategy, often as an explicit policy goal that came as part of Washington Consensus policies. Such a strategy however is not purely a matter of policy choice but reflects the restructuring of global production described in the previous section: in general, ECEs occupy a structurally subordinate position within GPNs, favouring a role as producer of primary commodities, intermediate goods, and consumer goods 
for export. ACEs, and chiefly the United States, have played the counterpart role of the importers, as "debt-financed excess spending from the capital gains of a housing boom turned Americans into the world's buyers of the last resort absorbing the export-led growth of Europe and of many emerging market economies" (Guttmann, 2016: 140).

Export-led growth shapes the process of financialization in ECEs in particular ways. At first glance, there is evidence that this growth model reduces the scope for many financialized practices that are typically associated with debt-led economies. In most countries where exports are the key lever of aggregate demand, there is evidence that countries experience lower levels of household indebtedness and less pronounced real estate booms (Karwowski and Stockhammer, 2017; Mertens, 2017). Nevertheless, as discussed, financialization seen as a global secular phenomenon goes deeper than its cyclical quantitative manifestations. Its structural secular dimensions manifest in ECEs in a way that is mediated by their export-led structure.

First, the proceeds from exports can be channeled towards domestic and international financial markets. As exporters in ECEs realize profits, subdued domestic demand may limit the opportunities for profitable investment. Just like in advanced economies, NFCs and wealthy individuals may then be led to invest in financial markets. There is evidence that NFCs have accumulated a growing share of assets in financial investments, often at the detriment of fixed capital formation (Correa et al.,2012; Demir,2007; Karwowski,2015; Seo et al.,2012; Tori and Onaran,2017). Furthermore, inequalities in the distribution of wealth and income fueled financial asset demand, as large profits were distributed in the hands of high-net worth individuals, fueling stock market booms in several ECEs (Akyüz 2017). A form of "elite financialization" developed in those countries where domestic financial rates of returns - e.g. high interest rates to attract capital inflows - made it possible for wealthier sections of the population to find remunerative savings vehicles (Araújo et al., 2012; Becker et al., 2010). Nevertheless, given the small capacity of ECEs' financial markets as well as their subordination in the global financial system, a large share of this wealth has been invested into ACEs (Goda et al., 2017; Lysandrou, 2011).

Second, export-led growth has contributed to the accumulation of foreign exchange reserves, where central banks have intervened in the foreign exchange markets. In those countries which experienced current account surpluses - by accident or 'neo-mercantilist' design - net exports directly fuelled the accumulation of reserves (Painceira 2009). But even in those 'unsuccessful' export-led ECEs, which did not produce substantial current account surpluses, reserves accumulation proceeded on the back of substantial foreign capital inflows (Levy-Orlik 2014; Luna 2015). Accumulation of reserves paradoxically represents both a reaction to financialization dictated by export orientation, and its strengthening: they allow ECEs to act in foreign exchange markets, and thus contain exchange rate volatility, which can have severe destabilizing effects on exports; but they simultaneously represent wealth that is channeled to financial markets, through vehicles such as Sovereign Wealth Funds, in a way not dissimilar to the portfolio of wealthy private investors (Monk, 2011). As discussed further below, these reserves have also been instrumental in driving the development of domestic financial markets (Lapavitsas 2014; Painceira 2012).

Third, financialization may provide ways to support export orientation through its engagement with households. Reforms of social security systems, involving greater reliance on financial markets, have been part of the restructuring of the economy towards export-led growth, often coming as a part of neoliberal "policy packages" (Becker et al., 2010; Correa et al., 2012; Cosar and Yegenoglu, 2009; Lavinas, 2017). Finance has therefore served as an engine to establish privatized forms of social reproduction, as the competitive pressures of export orientation and the need to keep a country's position within GPNs limit the scope for public provision of welfare. Through 
these reforms households in ECEs have come to depend to a greater extent on financial markets, through the expansion of private pension funds, pooled investment systems, and easier access to credit including for housing purchases (Correa et al. 2012; Rethel 2010). Furthermore, credit extension can also work as a disciplining mechanism, undermining the resistance of indebted workers (Karacimen, 2015; Mader, 2015).

While export orientation represents a key tendency in the majority of ECEs, there have been exceptions. For example, there is evidence that in some ECEs forms of debt-financed consumption have taken place: household debt expansion has at least partly contributed to stimulate aggregate demand in South Africa (Newman, 2014), Brazil (Lavinas, 2017), Slovakia (Becker et al., 2010) and Malaysia (Rethel, 2010). Finance has therefore worked as a 'relief valve' for domestic aggregate demand even in ECEs, at least temporarily. It is not surprising therefore that indebtedness in ECEs has increased in the post-crisis period, as the US tempered its role as global 'buyer of last resort', thus limiting the potential of export-led growth.

In sum, financialization can be understood as an aid to circulation and profit realization by stimulating aggregate demand globally. In this, ECEs have mainly - though not exclusively - played a role of exporters to debt-led economies, chiefly the US as the 'buyer of last resort'. The forms of financialization in ECEs are therefore fundamentally shaped by this phenomenon, as corporations and central banks accumulate wealth that is channeled towards financial assets, fostering the development of financial markets and financial innovation domestically, and households increasingly engage with financial markets to manage those activities necessary to social reproduction. The precise forms taken vary according to each nation's particular involvement with these structural features.

\section{Internationalization of Finance}

The final change in global capital accumulation we want to highlight is the tremendous increase in international financial markets, their changing nature, and ECEs' shifting and subordinate integration into them. . Moreover, ECEs' integration into these global markets has also changed, in a process which could be considered the international aspect of financialization (Bortz and Kaltenbrunner, 2017).

First, in line with the expansion of global finance, ECEs' external assets and liabilities rose from under 33\% to more than $130 \%$ of their GDP between 1970 and 2013. Capital inflows and outflows rose from 3.52 per cent and 2.22 per cent of GDP in 1976-85 to more than 6 per cent and nearly 8 per cent respectively in 2006-15 (Bortz and Kaltenbrunner, 2017).

Second, the nature of these flows has changed and has become highly complex characterized by new instruments, markets and international actors. As to the actors, traditional investors in ECEs (such as banks and dedicated funds) have been joined by a wide range of other actors, including institutional investors (pension, mutual and insurance funds) (Bonizzi, 2017b) and new types of mutual fund investors such as exchange-traded funds and macro hedge funds (Aron et al., 2010; Jones, 2012; Yuk, 2012). Given the enormous size of these financial investors, even a small reallocation of their portfolio can have a substantial impact on capital flows to ECEs. Moreover, these different actors have diverse investment strategies and funding patterns, substantially increasing the complexity of foreign investment. With regards to the instruments and markets, foreign investors have gained access to a wider set of (domestic currency) assets, such as equities, derivatives, and local bond markets (Kaltenbrunner and Painceira, 2015, Akyüz, 2017). 
Kaltenbrunner and Painceira (2015) argue that the returns of these assets are often based on capital gains, rather than investment income, which potentially increases the volatility of capital flows and increases the importance of open and liquid financial markets for portfolio adjustment. In the case of domestic currency assets, the exchange rate becomes an important element of these capital gains, resulting in destabilizing feedback dynamics not only in asset prices but also the exchange rate.

Third, the relation between domestic actors and international financial markets has tightened considerably. As discussed above, NFCs from ECEs have become active players on international financial markets and internationalized their balance sheets. ECEs' banks have expanded internationally, partly accompanying the increase in outward FDI, partly offering their rich domestic clients new investment opportunities abroad, and partly on their own account (World Economic Forum, 2012). In many ECEs household lending has surged, in several of them largely denominated in foreign currency (Gabor, 2010).

In line with the broader argument, these changes in ECEs' financial integration were shaped by their subordinate position in the international financial and monetary system which manifested itself both in the nature of their international financialization and its implications. As to the former, although ECE public actors could borrow increasingly in domestic currency (less so private ones which had to rely largely on international dollar funding as discussed above) and seemingly move away from their traditional 'original sin', foreign financial flows to those countries have remained relatively volatile. They have been dominated by short-term financial return considerations rather than productive, long-term investment. One example are the notorious carry trade operations, where financial actors borrow in low interest rate currencies, such as the Japanese Yen or the US Dollar, and invest in high-interest ECE currencies, taking advantage of the interest rate differential and very often sustained periods of exchange rate appreciation caused by those same carry trade operations. These high interest rates and profitable exchange rate movements, in turn, are an expression of ECEs' international monetary subordination necessary to compensate for these currencies' lower standing in the international currency hierarchy.

Even long-term investors and those invested in domestic assets remain funded on international financial markets which maintains their sensitivity to international market conditions and depreciation pressures on ECEs' assets and currencies as funds need to be repatriated in the future. For example, Bonizzi (2017b) shows that despite their longer time horizons pension fund investment in ECEs will not act as a stabilizing force due to their need to match their liabilities, which are predominantly located in the capitalist core. Finally, probably one of the clearest manifestations of ECEs subordinated position in international finance has been the phenomenon of reserve accumulation. As mentioned in the previous section, rather than being channeled into the economy, billions of dollars have been absorbed by ECE central banks to protect against future capital outflows (and frequently to deal with the exchange rate volatility associated with both capital in- and outflows).

Though still quite limited, several authors have shown how these aspects of ECEs' financial integration have shaped domestic financialization processes. For example, volatile capital and exchange rate movements tighten economic actors', in particular NFCs', relations to derivatives and financial markets more generally (Coutinho and Belluzzo, 1998, Correa et al. 2012; Akkemik and Özen, 2014). Painceira (2011) shows convincingly, in the case of Brazil and South Korea, how reserve accumulation and consequent sterilization operations (the sale of short-term government bonds by the central bank to absorb the additional money created from its foreign exchange purchases) contributed to the financialization of banks (reflected in an expansion of balance 
sheets and increase in market funding) and households (through consumption loans). According to his argument, domestic banks used the sterilization bonds issued by the central banks to (a) increase their own short-term funding and (b) use this short-term funding to increase their lending to households.

In sum, in addition to changes in the international organization and realization of production, the changing nature of international financial markets themselves have contributed fundamentally to financialisation processes in ECEs. On the one hand this refers to the growing but subordinate nature of ECE financial integration, which is dominated by short-term capital flows that remain funded in ACE currencies. On the other hand, such integration has fundamentally shaped the financial practices of domestic agents, such as the holding of financial assets by NFCs and the expansion of bank loans for consumption.

\section{Conclusions}

It has been argued that ECEs' financialization emerges and is fundamentally shaped by the subordinate nature of their integration into the world economy. We have examined how this has played out across production, circulation and finance. In production, the global disaggregation of production networks, and ECE firms' emerging leadership and/or integration into these networks, has given rise to new financial practices and relations through the centralization of profits, and novel risks, opportunities and pressures. In circulation, ECEs' integration into a global system of surplus realization and the need to boost domestic demand through exports has provided impetus for the increased depth and sophistication of domestic financial markets and exerted pressures on systems of social reproduction. In finance, the increased size and complexity of international financial integration has drawn ECE agents, instruments, and markets deeper into the remit of global financial markets. In all three spheres, these processes have been mediated by ECEs' subordinate position in global production and finance, which has both contributed to financialization in these countries (e.g. through the heightened volatility of domestic asset prices and the exchange rate) and given it its specific forms (e.g. the importance of foreign currency operations).

The argument has an important corollary. Not only has financialization been mediated by ECEs' global subordination, but these same processes of financialization may serve to cement or even deepen their subordination in the global hierarchy of nations. Financialization will benefit lead firms of global production networks, still located predominantly in ACEs, which are able to channel profits into financial markets and deploy financialized strategies. The costs of engaging in GPNs will be relatively higher for ECE firms. At the same time, many of the ECE firms which have acquired global leadership and been able to profit from increasingly sophisticated financial markets have been from traditionally strong sectors such as mining and raw materials (at least in the case of Latin America and Africa), whereas other sectors involving high-risk innovation have suffered from the increased volatility and risk brought by financialized capitalism. From the perspective of circulation, insofar as financialization reinforces export orientation, this makes ECEs more vulnerable to the volatility of an ever more finance-dominated global demand, the relative decline of which has created several problems for ECEs in the post-crisis era. On the financial side, financialization has helped to maintain relatively high interest rates, and exacerbate external vulnerability and asset price volatility, rendering it yet more difficult to overcome subordination through attracting more stable long-term investment and/or developing domestic financial markets. 
The implications of both cyclical processes of financialization and secular changes associated with financialized capitalism across the uneven hierarchy of global capitalism remain underexplored. More research is needed on the concrete ways in which the uneven nature of international finance and production are both shaped by and exacerbate changes in the financial relations and practices of global, regional and national economic actors. 


\section{References}

Akkemik, K. A. and Özen, Ş (2014). Macroeconomic and Institutional Determinants of Financialisation of Non-Financial Firms: Case Study of Turkey. Socio-Economic Review, 12(1): 7198.

Akyüz, Y. (2017). Playing with Fire: Deepened Financial Integration and Changing Vulnerabilities of the Global South. Oxford, Oxford University Press.

Araújo, E., Bruno, M. And Pimentel, D. (2012). Financialization Against Industrialization: a Regulationist Approach of the Brazilian Paradox. Revue de La Régulation. Capitalisme, Institutions, Pouvoirs (11).

Aron, J., Leape, J. and Thomas, L. (2010). Portfolio and Capital Markets in South Africa. Paper presented at the CSAE Conference 2010 Economic Development in Africa, 21 - 23 March, Oxford.

Auvray, T. and Rabinovich, J. (2017). The Financialisation-Offshoring Nexus and the Capital Accumulation of US Nonfinancial Firms. Retrieved from https://hal.archives-ouvertes.fr/hal$\underline{01492373 / \text { document }}$

Bair, J. (2005). Global Capitalism and Commodity Chains: Looking Back, Going Forward. Competition \& Change, 9(2): 153-180.

Baud, C. and Durand, C. (2012). Financialization, Globalization and the Making of Profits by Leading Retailers. Socio-Economic Review, 10(2): 241-266.

Becker, J., Jager, J., Leubolt, B., \& Weissenbacher, R. (2010). Peripheral Financialization and Vulnerability to Crisis: A Regulationist Perspective. Competition and Change, 14(3-4): 225-247.

Bonizzi, B. (2013). Financialization in Developing and Emerging Countries. International Journal of Political Economy, 42(4): 83-107.

Bonizzi, B. (2017a). An Alternative Post-Keynesian Framework for Understanding Capital Flows to Emerging Markets. Journal of Economic Issues, 15(1): 137-162.

Bonizzi, B. (2017b). Institutional Investors' Allocation to Emerging Markets: A Panel Approach to Asset Demand. Journal of International Financial Markets, Institutions and Money, 47: 47-64.

Bortz, P. G. and Kaltenbrunner, A. (2017). The International Dimension of Financialization in Developing and Emerging Economies. Development and Change, 49(2): 375-393.

Boyer, R. (2000). Is a Finance-led Growth Regime a Viable Alternative to Fordism? A Preliminary Analysis. Economy and Society, 29(1): 111-145.

Bruno, V. and Shin, H.S. (2015). Global Dollar Credit and Carry Trades: A Firm-level Analysis. BIS Working Paper 51.

Carmody, P. (2002). Between Globalisation and (post) Apartheid: The Political Economy of Restructuring in South Africa. Journal of Southern African Studies, 28(2): 255-275. 
Correa, E., Vidal, G. and Marshall, W. (2012). Financialization in Mexico: Trajectory and Limits. Journal of Post Keynesian Economics, 35(2): 255-275.

Cosar, S. and Yegenoglu, M. (2009). The Neoliberal Restructuring of Turkey's Social Security System. Monthly Review, 60(11): 36-49.

Coutinho, L. G. and Belluzzo, L. G. d. M (1998). Financeirização da Riqueza, Inflação de Ativos e Decisões de Gasto em Economias Abertas. Economia e Sociedade, 11: 137-150.

Crouch, C. (2009). Privatised Keynesianism: An Unacknowledged Policy Regime. The British Journal of Politics \& International Relations, 11(3): 382-399.

Cynamon, B. Z. and Fazzari, S. M. (2008). Household Debt in the Consumer Age: Source of Growth--Risk of Collapse. Capitalism and Society, 3(2), article 3.

Demir, F. (2007). The Rise of Rentier Capitalism and the Financialization of Real Sectors in Developing Countries. Review of Radical Political Economics, 39(3): 351-359.

Demir, F. (2009). Financialization and Manufacturing Firm Profitability under Uncertainty and Macroeconomic Volatility: Evidence from an Emerging Market. Review of Development Economics, 13(4): 592-609.

Durand, C. and Gueuder, M. (2016). The Investment-Profit Nexus in an Era of Financialisation and Globalisation. A Profit Centred Perspective. Post Keynesian Economics Study Group Working Paper 1614.

Farhi, M. and Borghi, R. (2009). Operações com Derivativos Financeiros das Corporações de Economias Emergentes no Ciclo Recente. Estudos Avançados, 23(66): 169-188.

Gabor, D. (2010). Central Banking and Financialization: a Romanian Account of How Eastern Europe Became Subprime. Basingstoke, Palgrave Macmillan.

Gereffi, G., Humphrey, J. and Sturgeon, T. (2005). The Governance of Global Value Chains. Review of International Political Economy, 12(1): 78-104.

Goda, T., Onaran, Ö. and Stockhammer, E. (2017). Income Inequality and Wealth Concentration in the Recent Crisis. Development and Change, 48(1), 3-27.

Graser, S. (2010). Realwirtschaftliche und Finanzwirtschaftliche Internationalisierung: Die besondere Relevanz fuer Emerging Market Multinationals. Wiesbaden, Gabler Verlag.

Guttmann, R. (2016). Finance-Led Capitalism: Shadow Banking, Re-Regulation, and the Future of Global Markets. Basingstoke, Palgrave Macmillan.

Harvey, D. (2011). The Enigma of Capital: And the Crises of Capitalism. London: Profile Books.

Hein, E. (2012). Finance-dominated Capitalism, Re-distribution, Household Debt and Financial Fragility in a Kaleckian Distribution and Growth Model. PSL Quarterly Review, 65(260): 11-51. 
Hiratuka, C. and da Rocha, M. (2015). Grandes Grupos no Brasil: Estrategias e Desempenho nos Anos 2000. Ipea Texto para Discussao 2049.

Hiratuka, C. and Sarti, F. (2011). Investimento Direto e Internationalizacao de Empresa Brasileiras no Periodo Recente. Ipea Texto para Discussao 1610.

Jones, S. (2012). 'Macro Funds Seek Succour in Emerging Markets'. Financial Times, 24th October.

Kaltenbrunner, A. (2015). A Post Keynesian Framework of Exchange Rate Determination: A Minskyan Approach. Journal of Post Keynesian Economics, 38(3): 426-448.

Kaltenbrunner, A. and Lysandrou, P. (2017). The US Dollar's Continuing Hegemony as an International Currency: A Double-matrix Analysis. Development and Change, 48(4): 663-691.

Kaltenbrunner, A. and Painceira, J.P. (2015). Developing Countries' Changing Nature of Financial Integration and New Forms of External Vulnerability: The Brazilian Experience. Cambridge Journal of Economics, 39(5): 1281-1306.

Kaltenbrunner, A. and Painceira, J.P. (2016). "International and Domestic Financialisation in Middle Income Countries: The Brazilian Case." FESSUD Working Paper 146. Retrieved from http://fessud.eu/working-papers/\#WP6).

Karacimen, E. (2015). Interlinkages Between Credit, Debt and the Labour Market: Evidence from Turkey. Cambridge Journal of Economics, 39(3): 751-767.

Karwowski, E. (2012). Financial Operations of South African Listed Firms: Growth and Financial Stability in an Emerging Market Setting. iii conferencia international do ieSe, Mozambique September. Retrieved from: www.iese.ac.mz/lib/publication/III Conf2012/IESE IIIConf Paper6.pdf

Karwowski, E. (2015). The Finance-Mining Nexus in South Africa: How Mining Companies Use the South African Equity Market to Speculate. Journal of Southern African Studies, 41(1): 9-28.

Karwowski, E. and Stockhammer, E. (2017). Financialisation in Emerging Economies: A Systematic Overview and Comparison with Anglo-Saxon Economies. Economic and Political Studies, 5(1): 60-86.

Lane, M.P.R. and Milesi-Ferretti, M.G.M (2017). International Financial Integration in the Aftermath of the Global Financial Crisis. IMF Working Paper 115.

Lapavitsas, C. (2014). Profiting Without Producing: How Finance Exploits Us All. London, Verso Books.

Lavinas, L. (2017). How Social Developmentalism Reframed Social Policy in Brazil. New Political Economy, 22(6): 628-644.

Levy-Orlik, N. (2014). Financialisation in Unsuccessful Neo-Mercantilist Economies: External Capital Inflows, Financial Gains and Income Inequality. Limes+, XI(3): 147-175. 
Luna, V. M. I. (2015). Foreign Exchange Reserves Accumulation in Latin America During the Current Crisis. Economía Informa, 392L 3-13.

Lysandrou, P. (2011). Global Inequality and the Global Financial Crisis: The New Transmission Mechanism. In J. Michie (Ed.), The Handbook of Globalisation: 495-517. Cheltenham, Edward Elgar.

Mader, P. (2015). The Political Economy of Microfinance: Financializing Poverty. Basingstoke, Palgrave Macmillan.

Magdoff, H. and Sweezy, P. M. (1987). Stagnation and the Financial Explosion. New York, Monthly Review Press.

Mathews, J. A. (2006). Dragon Multinationals: New Players in 21st Century Globalization. Asia Pacific Journal of Management, 23(1): 5-27.

McCauley, R., McGuire, P. and Shushko, V. (2015). Dollar Credit to Emerging Economies. BIS Quarterly Review December: 27-41.

Mertens, D. (2017). Putting 'Merchants of Debt' in their Place: The Political Economy of Retail Banking and Credit-based Financialisation in Germany. New Political Economy, 22(1): 12-30.

Milberg, W. (2008). Shifting Sources and Uses of Profits: Sustaining US Financialization with Global Value Chains. Economy and Society, 37(3): 420-451.

Milberg, W. and Winkler, D. (2010). Financialisation and the Dynamics of Offshoring in the USA. Cambridge Journal of Economics, 34(2):275-293.

Monk, A. H. B. (2011). Sovereignty in the Era of Global Capitalism: The Rise of Sovereign Wealth Funds and the Power of Finance. Environment and Planning A: Economy and Space, 43(8):18131832.

Montalban, M. and Sakinç, M.E. (2013). Financialization and Productive Models in the Pharmaceutical Industry. Industrial and Corporate Change, 22(4): 981-1030.

Newman, S. (2014). Financialisation and the Financial and Economic Crises: The Case of South Africa. Financialisation, Economy, Society \& Sustainable Development (FESSUD) Project. Retrieved from https://econpapers.repec.org/paper/fesfstudy/fstudy26.htm

Painceira, J. P. (2009). Developing Countries in the Era of Financialisation: From Deficit Accumulation to Reserve Accumulation. Research on Money and Finance Discussion Paper 4. Retrieved from http://ideas.repec.org/p/rmf/dpaper/04.html

Painceira, J. P. (2011). Central Banking in Middle Income Countries in the Course of Financialisation: A Study with Special Reference to Brazil and Korea. PhD Dissertation, SOAS, University of London.

Painceira, J. P. (2012). Financialisation, Reserve Accumulation and Central Bank in Emerging Economies: Banks in Brazil and Korea. Research on Money and Finance Discussion Paper 38. 
Palloix, C. (1975). L'economie mondiale capitaliste, Paris, François Maspero.

Palpacuer, F., Perez, R., Tozanli, S. and Brabet, J. (2006). Financiarisation et Globalisation des Stratégies d'Entreprise : Le Cas des Multinationales Agroalimentaires en Europe. Finance Contrôle Stratégie, 9(3): 165-189.

Pelletier, A. (2018). Performance of Foreign Banks in Developing Countries: Evidence from SubSaharan African Banking Markets. Journal of Banking \& Finance, 88, 292-311.

Powell, J. (2013). Subordinate Financialisation: A Study of Mexico and its Non-Financial Corporations. PhD dissertation, SOAS, University of London.

Powell, J. (2018). Towards a Marxist Theory of Financialized Capitalism. In: The Oxford Handbook of Karl Marx, Prew, P. et al. (eds.), New York, Oxford University Press.

Prates, D. M. and Andrade, R. (2013). Exchange Rate Dynamics in a Peripheral Monetary Economy. Journal of Post Keynesian Economics, 35(3): 399-416.

Randøy, T., Oxelheim, L. and Stonehill, A. (2001). Corporate Financial Strategies for Global Competitiveness. European Management Journal, 19(6): 659-669.

Rethel, L. (2010). Financialisation and the Malaysian Political Economy. Globalizations, 7(4): 489-506.

Seo, H. J., Kim, H. S. and Kim, Y. C. (2012). Financialization and the Slowdown in Korean Firms' R\&D Investment. Asian Economic Papers, 11(3): 35-49.

Stockhammer, E. (2015). Rising Inequality as a Cause of the Present Crisis. Cambridge Journal of Economics, 39(3): 935-958.

Toporowski, J. (2009). International Business and the Crisis. Critical Perspectives on International Business, 5(1/2): 162-164.

Tori, D. and Onaran, Ö. (2017). Financialisation and Physical Investment: A Global Race to the Bottom in Accumulation? Post Keynesian Economics Study Group Working Paper 1707

Unctad (2007). Global Players from Emerging Markets: Strengthening Enterprise Competitiveness Through Outward Investment. Geneva.

World Economic Forum (2012). Financial Development Report. New York, World Economic Forum.

Yuk, P. (2012). The Rise of Emerging Markets ETFs. Financial Times, 18th October. 